\title{
STRESS AMONG NURSES WORKING IN CRITICAL CARE AREAS AT A TERTIARY CARE TEACHING HOSPITAL NEPAL RK MEHTA ${ }^{1 *}$, IK SINGH ${ }^{2}$ \\ ${ }^{1}$ College of Nursing, Chitwan Medical College, Bharatpur, Chitwan, Nepal. ${ }^{2}$ BP Koirala Institute of Health Sciences, Dharan, Nepal.
}

*Correspondence to: Mr. Raj Kumar Mehta, Associate Professor, College of Nursing, Chitwan Medical College, Bharatpur, Chitwan, Nepal, Email: mehtarajk@yahoo.com

\begin{abstract}
Stress is a part of our life. Stress can also create positive and negative influence in our daily lives. As a positive influence stress is a motivating force towards progress and it can create new awareness and exciting new perspective. As a negative influence it creates feeling of distress, rejection, depression, which leads to variety of physical and psychological problems. The aim of the study was to assess stress among nurses working in critical care areas at BPKIHS.

A Descriptive explorative design was used to conduct the study in critical care areas of BPKIHS Dharan. Fifty staff nurses working in critical care areas with at least one year of critical care experience were included in this study. Random sampling technique was used to select the sample from random number table. Self administered structured questionnaire and Modified Expanded Nursing Stress Scale were used for the collection of data.

Study findings revealed that majority of the respondents $56 \%$ had moderate stress followed by mild stress $34 \%$, sever stress $6 \%$, where as very less number of respondents $4 \%$ had no stress in their job setting. This study finding also indicate that Nepalese nurses rated factors such as lack of opportunity to discuss problems with peers $36 \%$ and inadequate emotional preparation $30 \%$, being sexually harassed $24 \%$, experiencing discrimination because of race or ethnicity $20 \%$, and experiencing discrimination on the basis of gender $10 \%$ as low on the stress scale. Stress factors rated "Moderately and very much stressful" were shortage of staff to adequately cover the unit $82 \%$, being blamed for anything that goes wrong $70 \%$, not enough equipment supplies/ not functioning well $62 \%$, physician not being present in a medical emergency $62 \%$, patients' family making unreasonable demands $62 \%$, lack of support from nursing administration $52 \%$, having to work through breaks $54 \%$, not enough time to complete all nursing tasks $46 \%$.

This study provides valuable insight into the actual and perceived stressful experiences of critical care nurses, thus contributing to the ongoing effort to reduce burnout in this population.
\end{abstract}

Key Words: Critical Care, Nurse, Nursing, Work, Stress.

\section{INTRODUCTION}

According to the Global Advisory Group of the World Health Organization, there is a worldwide shortage of nurses. Regardless of country, this shortage has an impact upon the care delivered to patients, as well as the physical and mental health of nurses. ${ }^{1}$

On the threshold of a new century, nurses are well positioned to influence the diverse trends impacting on health care and nursing. The major trends can be monitored and their impact can be analyzed to help guide future planning and action. In U.K. total of 342 nurses committed suicide in the six years i.e. 1992 to 1998 , a rate of 11 per 100,000. Stress and depression are like a virus: You catch it at work and take it. ${ }^{2}$

Stress occurs when there are demands on the person which exceed his adaptive resources. Eustress causes increased mental activity, pleasure and euphoria, which can be constructive. On the other hand distress can cause reduced attention, forgetting, poor work performance all of which can be potentially dangerous for critical care unit nurses. ${ }^{3}$

Within the hospital context, the intensive care units have already been the focus of several research studies related to nurses' stress. It is known that this sector in the hospital is tasked with caring for patients in an acute or critical state, but within the possibility of recovery; patients who require specialized, permanent medical and nursing care; patients subject to having unstable vital functions, who need the support of special equipment for treatment and diagnosis. ${ }^{4}$

Nursing profession has been considered a stressful occupation. Nurses are always facing challenges both externally and internally whether it is work related or outside the work place. The stressors include: dealing with death and dying patients; 
conflicts with colleagues, lack of skill and training, frequent changes in technology, lack of protocol and guidance, unequal power balance between doctor and nurses, demand from the public and heightened public awareness about health and their right.

We agree that nursing is, among other occupations, quite stressful. When treating critical patients, it is even considered wearisome, and being a part of such day - to- day routine makes the nurse susceptible to stress. In face of these inquires, the present study is performed, aiming to identify the stress agents and the coping strategies by nurses working in critical care areas. This research can lay the foundation of effective intervention programs to reduce the tension in the work environment of nurses.

\section{MATERIALS AND METHODS}

A hospital- based, Quantitative and descriptive explorative design was used to conduct the study in critical care areas (ICU, CCU, NICU, PICU, MICU \& Emergency ward) of BPKIHS. Total 50 staff nurses working in critical care areas with at least one year of critical care experience were included in this study. Random sampling technique was used to select the sample from random number table. Self administered structured questionnaire and Standardized tool, Modified Expanded
Nursing Stress Scale (ENSS) were used for the collection of data. Written consent was taken from each respondent. Privacy, confidentiality and anonymity was assured and maintained. Data were summarized by using descriptive statistical method.

\section{RESULTS AND DISCUSSION}

The present study was undertaken to evaluate job related stress factors among the nurses working in critical care areas at BPKIHS, Nepal. Role conflict and workload were linked to poor motivation and performance and more absenteeism among nurses. Job dissatisfaction resulting from lack of independence and decision making power has been associated with poor provision of care and breakdown communication between patient and staff.

\section{Socio Demographic Characteristics}

Majority of the respondents $(66 \%)$ were in the age group between 20-25 years. The mean age of respondent was about 24 years. It was found that $74 \%$ of the respondents were unmarried, $98 \%$ of the respondents were educated up to certificate level nursing, $52 \%$ of the respondents had work experience as a nurse between 2-5 years, and 54\% respondents had work experience $<2$ years in critical care areas. Most of the respondents $(30 \%)$ were from emergency unit (Table 1).

Table 1: Socio Demographic Characteristics of Study Participants $(\mathrm{n}=\mathbf{5 0})$

\begin{tabular}{|c|c|c|c|}
\hline Characteristics & Category & No & $\%$ \\
\hline \multirow{4}{*}{ Age (in years) } & $<25$ & 33 & 66 \\
\hline & $25-30$ & 14 & 28 \\
\hline & $30-35$ & 3 & 6 \\
\hline & \multicolumn{3}{|c|}{ Mean Age: 23.50} \\
\hline \multirow{2}{*}{ Marital Status } & Unmarried & 37 & 74 \\
\hline & Married & 13 & 26 \\
\hline \multirow{2}{*}{ Level of Nursing Education } & Certificate & 49 & 98 \\
\hline & Bachelor & 1 & 2 \\
\hline Post & Staff Nurse & 50 & 100 \\
\hline \multirow{5}{*}{ Years worked as a Nurse } & $<2$ & 18 & 36 \\
\hline & $2-5$ & 26 & 52 \\
\hline & $5-10$ & 5 & 10 \\
\hline & $>10$ & 1 & 2 \\
\hline & \multicolumn{3}{|c|}{ Mean: 2.61} \\
\hline \multirow{5}{*}{ Years Worked in Critical care areas } & $<2$ & 27 & 54 \\
\hline & $2-5$ & 19 & 38 \\
\hline & $5-10$ & 3 & 6 \\
\hline & $>10$ & 1 & 2 \\
\hline & \multicolumn{3}{|c|}{ Mean : 2.25} \\
\hline
\end{tabular}

Scores of Expanded Nurses stress scale for job Related Stress

Majority of the respondents (56\%) had moderate stress followed by mild stress $(34 \%)$, severe stress $(6 \%)$, where as very less number of respondents (4\%) had no stress in their job setting (Table 2). 
Mehta et al, Journal of Chitwan Medical College 2014; 4(10)

Table 2: Scores of Expanded Nurses stress scale for job Related Stress $(\mathbf{n}=\mathbf{5 0})$

\begin{tabular}{|c|c|c|c|}
\hline Characteristics & Category & No. & $\%$ \\
\hline \multirow{4}{*}{$\begin{array}{l}\text { Workload stressor, } \\
\text { Problems with supervision stressors, problems with } \\
\text { peers stressors, conflict with physician stressors, } \\
\text { death and dying stressor, inadequate emotional } \\
\text { preparation stressors, uncertainty concerning } \\
\text { treatment stressors, patient and family stressor and } \\
\text { discrimination stressors }\end{array}$} & $\begin{array}{c}\text { No Stress } \\
(\text { Score: } \leq 50)\end{array}$ & 2 & 4 \\
\hline & $\begin{array}{c}\text { Mild Stress } \\
\text { (Score : } 51-100\end{array}$ & 17 & 34 \\
\hline & $\begin{array}{c}\text { Moderate Stress } \\
\text { (Score : } 101-150)\end{array}$ & 28 & 56 \\
\hline & $\begin{array}{c}\text { Severe stress } \\
\text { (Score : } 151-200)\end{array}$ & 3 & 6 \\
\hline
\end{tabular}

\section{Workload stressors}

Majority of the subjects $82 \%$ had greater stress because of shortage of staff followed by not enough equipment supply / not functioning well $62 \%$, having to work through breaks $54 \%$, having to make decision under pressure $46 \%$, not enough time to complete all of nursing tasks $46 \%$, too many non-nursing task required such as clerical work $36 \%$ (Table 3). Findings are similar with a study conducted among Greek nurses by Brokalaki $\mathrm{H}$ et al where $74 \%$ had greater because of shortage of nursing personnel, increased responsibilities $65 \% .{ }^{5}$ Andrew Mc. V, who carried out a study on work place stress in nursing, also highlighted that workload were most stressful which were similar to a study done in Nepal by Mehta and Chaudhary. ${ }^{6,7}$ It is known that staffing patterns in hospitals throughout the Nepal have been dramatically impacted because of the critical care nurses shortage and the highest turnover of current nursing workforce. It justified that on the basis of lack of staffing hospital demonstrated "hardship" in filling these positions.

Table 3: Stress Factors Related workload $(n=50)$

\begin{tabular}{|c|c|c|c|c|}
\hline \multirow[b]{2}{*}{ Stress factors } & \multicolumn{4}{|c|}{ Stress Response \% } \\
\hline & $\begin{array}{c}\text { Never } \\
\text { stressful }\end{array}$ & $\begin{array}{l}\text { Slightly } \\
\text { Stressful }\end{array}$ & $\begin{array}{c}\text { Moderately } \\
\text { Stressful }\end{array}$ & $\begin{array}{c}\text { Very much } \\
\text { stressful }\end{array}$ \\
\hline Not enough time to provide emotional support to the patient & 24 & 46 & 24 & 6 \\
\hline Not enough time to respond to the needs of patients' families & 14 & 56 & 24 & 6 \\
\hline Not enough staff to adequately cover the unit & 2 & 16 & 34 & 48 \\
\hline Too many non-nursing tasks required, such as clerical work & 32 & 32 & 22 & 14 \\
\hline Not enough time to complete all of my nursing tasks & 16 & 38 & 16 & 30 \\
\hline Having to work through breaks & 12 & 34 & 28 & 26 \\
\hline Not enough equipment supply/not functioning well & 6 & 32 & 30 & 32 \\
\hline
\end{tabular}

\section{Problems with supervision stressors}

Not surprisingly, the lack of support by nursing administrators $52 \%$ was the major factors to produce stress followed by being held accountable for things over which nurses have no control $50 \%$, lack of support from immediate supervisor $40 \%$ and criticism by supervisor $36 \%$ (Table 4 ). Similar findings were reported by Andrew Mc V, Hsu Hc, Sawatzky, Mehta and Chaudhary, and Stordeur et al. ${ }^{3,67,8,9}$. They showed that the highest stress levels were related to management issues i.e. lack of supervision and support from supervisor, interruption in work from health administrators. Culturally; Nepalese nurse are highly influenced with supervisor and their roles and title. The supervisor is placed in the position with authority and therefore able to help in problem solving. When such help is unavailable or perceived as inadequate, the level of stress may be perceived higher.

Table 4 : Stress Factors Related to problems with supervision $(\mathrm{n}=50)$

\begin{tabular}{|l|c|c|c|c|}
\multicolumn{1}{|c|}{ Stress factors } & \multicolumn{3}{c|}{ Stress Response \% } \\
\cline { 2 - 5 } & $\begin{array}{c}\text { Never } \\
\text { stressful }\end{array}$ & $\begin{array}{c}\text { Slightly } \\
\text { Stressful }\end{array}$ & $\begin{array}{c}\text { Moderately } \\
\text { Stressful }\end{array}$ & $\begin{array}{c}\text { Very much } \\
\text { stressful }\end{array}$ \\
\hline Conflict with a supervisor & 24 & 42 & 20 & 14 \\
\hline Lack of support from immediate supervisor & 20 & 40 & 22 & 18 \\
\hline Criticism of support by nursing administrators & 26 & 38 & 12 & 24 \\
\hline Lack of support by nursing administrators & 22 & 26 & 18 & 34 \\
\hline Being held accountable for things over which I have no control & 30 & 20 & 26 & 24 \\
\hline Lack of support from other health care administrators & 22 & 36 & 22 & 20 \\
\hline
\end{tabular}




\section{Problems with peers stressors}

Lack of opportunity to talk openly with other personnel about problems in the work setting $44 \%$ was the major factor to produce stress followed by lack of opportunity to share experience and feelings with other personnel in the work setting $36 \%$, lack of opportunity to express to other personnel about the negative feelings towards patient $24 \%$, difficulty in working with a particular nurse in immediate work setting $24 \%$, difficulty in working with particular nurse outside immediate work setting $22 \%$, where as very less number of staff nurses of opposite sex
(Table 5). This finding contradicts to the finding observed in study by Elizabeth M A from California USA. ${ }^{10}$ The rising trend of patient admission, increasing emphasis on early discharge, give nurses little (if at all) to socialize or discuss problems with each other. This factor, rated low in the stress level scale may indicate peer discussion or support may have. Incidentally, it can be pointed out that one Nepalese cultural aspect here is that it is impolite to discuss issues openly. Since this is an accepted state, i.e. not talking openly, a Nepalese nurse could not rate this as very stressful.

to problems with peers $(n=50)$

\begin{tabular}{|c|c|c|c|c|}
\hline \multirow[b]{2}{*}{ Stress factors } & \multicolumn{4}{|c|}{ Stress Response \% } \\
\hline & $\begin{array}{c}\text { Never } \\
\text { stressful }\end{array}$ & $\begin{array}{l}\text { Slightly } \\
\text { Stressful }\end{array}$ & $\begin{array}{l}\text { Moderately } \\
\text { Stressful }\end{array}$ & $\begin{array}{l}\text { Very much } \\
\text { stressful }\end{array}$ \\
\hline Lack of opportunity to talk openly with other personnel about problems in the work setting & 20 & 36 & 26 & 18 \\
\hline $\begin{array}{l}\text { Lack of opportunity to share experiences and feelings with other } \\
\text { personnel in the work setting. }\end{array}$ & 22 & 32 & 20 & 16 \\
\hline $\begin{array}{l}\text { Lack of an opportunity to express to other personnel on the unit my } \\
\text { negative feelings towards patients }\end{array}$ & 64 & 12 & 20 & 4 \\
\hline Difficulty in working with a particular nurse (or nurses) in my immediate work setting & 40 & 36 & 16 & 8 \\
\hline Difficulty in working with a particular nurse (or nurses) outside my immediate work setting & 58 & 20 & 8 & 14 \\
\hline Difficulty in working with nurses of the opposite sex & 84 & 6 & 2 & 8 \\
\hline
\end{tabular}

\section{Conflict with physician stressors}

Making decision concerning a patient when a physician is unavailable $44 \%$ was the major factor to produce stress followed by conflict with physician $26 \%$, having to organize doctors work $24 \%$, criticism by a physician $20 \%$, where as very less number of staff nurses $12 \%$ has greater stress because of disagreement concerning the treatment of a patient (Table 6). Similar findings were reported by Li J, Lambert who carried out study among Chinese Nurses. ${ }^{11}$ Negative perception of one's work or how the staff nurse interacts with the physician in the

Table 6 : Stress Factors Related to conflict with physician $(n=50)$

\begin{tabular}{|c|c|c|c|c|}
\hline \multirow[b]{2}{*}{ Stress factors } & \multicolumn{4}{|c|}{ Stress Response \% } \\
\hline & $\begin{array}{c}\text { Never } \\
\text { Stressful }\end{array}$ & $\begin{array}{l}\text { Slightly } \\
\text { Stressful }\end{array}$ & $\begin{array}{c}\text { Moderately } \\
\text { Stressful }\end{array}$ & $\begin{array}{c}\text { Very Much } \\
\text { Stressful }\end{array}$ \\
\hline Criticism by a physician & 40 & 40 & 10 & 10 \\
\hline Conflict with a physician & 24 & 50 & 18 & 8 \\
\hline Disagreement concerning the treatment of a patient & 34 & 54 & 8 & 4 \\
\hline Making a decision concerning a patient when the physician is unavailable & 20 & 36 & 32 & 12 \\
\hline Having to organize doctors' work & 38 & 38 & 14 & 10 \\
\hline
\end{tabular}

\section{Death and dying stressors}

The physician not being present when a patient dies $62 \%$ was the major factor to produce stress followed by watching a patient suffer $58 \%$, death of a patient with whom nurses developed a close relationship 52\%, performing procedures that patient experience as painful $48 \%$, where as $44 \%$ of the respondents has greater stress because of feeling helpless in case of a patient who fails to improve and confined to death (Table 7). Findings are contradictory to in line with findings of Elizabeth $\mathrm{MA}^{10}$, who had reported that suffering was perceived work setting is an important variable in stress level rating. It can only be surmised that in a situation where a physician is unavailable, the nurse is forced to make a prudent decision, then a criticism results from such action resulting in a no-win situation. A nurse has to work under such circumstances and maintain professional composure. Such scenarios occurring repeatedly could possibly influence a nurse's decision to leave the source of stress, in this case may be request transfer to a different unit to avoid the physician in question. Some may chose to leave the hospital altogether.

as most stressful. Brokalaki $\mathrm{H}$ et $\mathrm{a}^{4}$ also found that $77 \%$ nurses had stress due to death of patient. One might envision a case scenario of inevitable death with the nurse ministering to the needs of both the patient and family. Indeed, one would have to be stoic, unattached or indifferent to not feel emotionally in pain. In the Nepalese culture, overt expression of emotion is not encouraged. Perhaps, even repression of an emotional state may be more stressful and certainly warrants further study. 
Mehta et al, Journal of Chitwan Medical College 2014; 4(10)

Table 7 : Stress factors Related to Death and Dying $(n=50)$

\begin{tabular}{|l|c|c|c|c|}
\multicolumn{1}{c|}{ Stress factors } & \multicolumn{3}{c|}{ Stress Response \% } \\
\cline { 2 - 5 } & $\begin{array}{c}\text { Never } \\
\text { stressful }\end{array}$ & $\begin{array}{c}\text { Slightly } \\
\text { Stressful }\end{array}$ & $\begin{array}{c}\text { Moderately } \\
\text { Stressful }\end{array}$ & $\begin{array}{c}\text { Very much } \\
\text { stressful }\end{array}$ \\
\hline Performing procedure that patients experience as painful & 16 & 36 & 38 & 10 \\
\hline Feeling helpless in the case of a patient who fails to improve & 10 & 46 & 20 & 24 \\
\hline The death of a patient & 14 & 42 & 28 & 16 \\
\hline The death of a patient with whom you developed a close relationship & 22 & 26 & 22 & 30 \\
\hline Physician (s) not being present when a patient dies & 20 & 18 & 14 & 48 \\
\hline Watching a patient suffer & 12 & 30 & 36 & 22 \\
\hline
\end{tabular}

\section{Inadequate emotional preparation stressors}

Being asked a question by a patient for which nurses do not have a satisfactory answer $42 \%$ was the major factor to produce stress where as feeling inadequately prepared to help with the emotional needs of a patient family $30 \%$ and feeling inadequately prepared to help with the emotional needs of a patient $26 \%$ rated less stressful factors by nurses (Table 8 ). These findings are similar to the study done by Elizabeth $\mathrm{M}$ $\mathrm{A}^{3}$ who reported that emotional preparation stressors were less

stressful. If we look at the totality of a patient care delivery system, there is a tremendous importance on the completion of routine procedures in an almost mechanistic fashion. There is focus on compliance with policies and procedures, as well as risk management. Hospital education departments generally address accreditation guidelines first, and staff nurses' preparation is approached from a skill-competence perspective, rather than emotional preparation.

Table 8: Stress Factors Related to Inadequate Emotional Preparation $(\mathbf{n}=50)$

\begin{tabular}{|l|c|c|c|}
\multicolumn{1}{|c|}{ Stress factors } & \multicolumn{2}{|c|}{ Stress Response \% } \\
\cline { 2 - 4 } & $\begin{array}{c}\text { Never } \\
\text { stressful }\end{array}$ & $\begin{array}{c}\text { Slightly } \\
\text { Stressful }\end{array}$ & $\begin{array}{c}\text { Moderately } \\
\text { stressful }\end{array}$ \\
\hline $\begin{array}{l}\text { Very much } \\
\text { stressful } \\
\text { peeling inadequately prepared to help with the emotional needs of a }\end{array}$ & 26 & 44 & 18 \\
\hline $\begin{array}{l}\text { Being asked a question by a patient for which I do not have a } \\
\text { satisfactory answer }\end{array}$ & 18 & 40 & 24 \\
\hline Feeling inadequately prepared to help with the emotional needs of a patient & 20 & 54 & 12 \\
\hline
\end{tabular}

\section{Uncertainty concerning treatment stressors}

The sample nurses rated that physician not being present in medical emergency, and inadequate information from a physician regarding the medical condition of a patient $48 \%$ was the major factor to produce stress followed by being exposed to health and safety hazards $46 \%$, physician ordering what appears to be inappropriate treatment for a patient $38 \%$, not knowing what a patient or a patient's family ought to be told about the patient's condition and its treatment $34 \%$, feeling inadequately trained for what a nurse have to do $30 \%$, uncertainty regarding the operation and functioning of specialized equipment $28 \%$ (Table 9). These findings are contradicted to Brokalaki
$\mathrm{H}^{5}$ and Li J, Lambet et $\mathrm{al}^{11}$ who reported that uncooperative family members and patients, the inability to reach physician, lack of clarity about tasks were major factors of stress. The sample population here has already registered to Nepal Nursing Council and has been in their current positions for at least one year. However, it is possible that some nurse are placed in "charge positions" particularly during the evening and night shifts when the usual charge nurse is on a sick time off or is on vacation. One's feeling of inadequacy can be additionally complicated when an emergency arises and the physician is not present at the time. 
Table 9: Stress factors related to uncertainty concerning treatment $(n=50)$

\begin{tabular}{|c|c|c|c|c|}
\hline \multirow[b]{2}{*}{ Stress factors } & \multicolumn{4}{|c|}{ Stress Response \% } \\
\hline & $\begin{array}{l}\text { Never } \\
\text { stressful }\end{array}$ & $\begin{array}{l}\text { Slightly } \\
\text { Stressful }\end{array}$ & $\begin{array}{l}\text { Moderately } \\
\text { stressful }\end{array}$ & $\begin{array}{l}\text { Very much } \\
\text { stressful }\end{array}$ \\
\hline $\begin{array}{l}\text { Inadequate information from a physician regarding the medical } \\
\text { condition of a patient. }\end{array}$ & 16 & 36 & 28 & 20 \\
\hline $\begin{array}{l}\text { A physician ordering what appears to be inappropriate treatment for a } \\
\text { patient }\end{array}$ & 32 & 30 & 24 & 14 \\
\hline Fear of making a mistake in treating a patient & 24 & 56 & 8 & 12 \\
\hline A physician not being present in a medical emergency & 14 & 38 & 24 & 24 \\
\hline Feeling inadequately trained for what I have to do & 22 & 48 & 16 & 14 \\
\hline $\begin{array}{l}\text { Not knowing what a patient or a patient's family ought to be told about } \\
\text { the patient's condition and its treatment. }\end{array}$ & 34 & 32 & 20 & 14 \\
\hline Uncertainty regarding the operation and functioning of specialized equipment & 26 & 46 & 16 & 12 \\
\hline Being exposed to health and safety hazards & 16 & 38 & 18 & 28 \\
\hline
\end{tabular}

\section{Patient and family stressor}

Being blamed for anything that goes wrong $70 \%$ was the major factor to produce stress followed by patient families making unreasonable demands $62 \%$, being the one that has to deal with patient's families $44 \%$, having to deal with abuse from patient's families $42 \%$, and not knowing whether patient's families will report nurses for inadequate care $40 \%$ (Table 10). The evening hours are particularly popular for visitors since many come after work periods. Family and friends provide much attention to the patient, possibly finding certain necessary components of careened to be brought to further attention of the nursing staff. Coping with patients, families and visitors place increased pressures on the daily routine care. Assigning "Blame" to the nurse is counterproductive but is the usual practice in many patient care units. Nursing managers should be particularly astute to look at causes of problems to solve them rather than "assigning blame". This would be ideal but practice reality does not "pause" for corrective action to take place. It is only on retrospective review that these issues can be addressed fully.

Table 10: Stress factors related to patient and family $(n=50)$

\begin{tabular}{|l|c|c|c|c|}
\multicolumn{1}{c|}{ Stress factors } & \multicolumn{3}{c|}{ Stress Response \% } \\
\cline { 2 - 5 } & $\begin{array}{c}\text { Never } \\
\text { stressful }\end{array}$ & $\begin{array}{c}\text { Slightly } \\
\text { Stressful }\end{array}$ & $\begin{array}{c}\text { Moderately } \\
\text { stressful }\end{array}$ & $\begin{array}{c}\text { Very much } \\
\text { stressful }\end{array}$ \\
\hline Patients' families making unreasonable demands & 10 & 28 & 22 & 40 \\
\hline Being blamed for anything that goes wrong & 8 & 22 & 24 & 46 \\
\hline Being the one that has to deal with patients' families & 30 & 26 & 36 & 8 \\
\hline Having to deal with abuse from patients' families & 20 & 38 & 20 & 22 \\
\hline Not knowing whether patients' families will report you for inadequate care & 32 & 28 & 24 & 16 \\
\hline
\end{tabular}

\section{Discrimination stressors}

Being sexual harassed $24 \%$ was major factor to produce stress followed by experiencing discrimination because of race or ethnicity $20 \%$, and experiencing discrimination because of race or ethnicity $20 \%$, and experiencing discrimination on the basis of gender 10\%(Table 11). Similar findings were reported by Elizabeth M A who had highlighted experiencing discrimination because of race or ethnicity and sexually harassed as lowest one. ${ }^{10}$ These are notable and reassuring results from this sample of Nepalese nurses. It may be because Nepalese nurses are recruited to help solve a staffing shortage that they are seen as being "helpful" and one might speculate that nurse managers and co-workers welcome them.

Table 11: Stress factors related to discrimination $(\mathbf{n}=50)$

\begin{tabular}{|l|c|c|c|c|}
\multicolumn{1}{c|}{ Stress factors } & \multicolumn{3}{c|}{ Stress Response \% } \\
\cline { 2 - 5 } & $\begin{array}{c}\text { Never } \\
\text { stressful }\end{array}$ & $\begin{array}{c}\text { Slightly } \\
\text { Stressful }\end{array}$ & $\begin{array}{c}\text { Moderately } \\
\text { stressful }\end{array}$ & $\begin{array}{c}\text { Very much } \\
\text { stressful }\end{array}$ \\
\hline Being sexually harassed & 70 & 6 & 6 & 18 \\
\hline Experiencing discrimination because of race or ethnicity & 62 & 18 & 8 & 12 \\
\hline Experiencing discrimination on the basis of gender & 66 & 24 & 2 & 8 \\
\hline
\end{tabular}




\section{CONCLUSION}

Results indicate that Nepalese nurses rated factors such as being sexually harassed, experiencing discrimination because of race or ethnicity, experiencing discrimination on the basis of gender, lack of opportunity to discuss problems with peers and inadequate emotional preparation as low on the stress scale. Stress factors rated "moderately and very much stressful" were shortage of staff to adequately cover the unit, being blamed for anything that goes wrong, not enough equipment/not functioning well, lack of support from nursing administration, physician not being present in a medical emergency having to work through breaks, not enough time to complete all nursing tasks, patient's family making unreasonable demands, unpredictable staffing and scheduling.

It seems imperative that nurses are assisted in identifying what they know, and that they are aided in applying knowledge to practice. Such a positive approach will motivate and nurture the confidence of nurses, creating positive socialization which in turn, increase job satisfaction and reduces levels of stress. This will allow the modification of the stress management program for the policy maker and organization to address specific factors rated as "most stressful".

\section{ACKNOWLEDGEMENT}

We would like to express our sincere gratitude to Aiti Maya Chhetri, Reader, Koshi Health and Science Campus, PU, Biratnagar and our great appreciation to Director, Dean, Nursing Chief, Head of departments and Incharge of critical care areas of BPKIHS, Dharan for granting permission for data collection.
REFERENCES

1. Healy C, McKay MF.Identifying sources of stress and job satisfaction in the nursing environment. Australian Journal of Advanced Nursing 1999;17:30-35.

2. Demerouti E, Baker A, Nachreiner F, Schaufeli WB.A model of burnout and life satisfaction amongst nurses. Journal of Advanced Nursing 2000;32:454-464.

3. French SE, Lenton R, Walters V, Eyles J.An empirical evaluation an expanded nursing stress scale. Journal of Nursing Measurement 2000;8:161-178.

4. Department of Health. Working Together- Learning Together. A Framework for Lifelong Learning for the NHS 2002. DH, London.

5. Brokalaki $\mathrm{H}$, et al. Job related stress among nursing personnel in Greek. J of Edtna Erca Oct-Dec 2001;27(4):181-186.

6. Andrew MV. Work place stress in Nursing: a literature review. Journal of Advance Nursing 2003;44(6):633642.

7. Maria RS. Stress and coping in nurse managers: Two decades of research. Nursing Economics 2006.

8. Sawatzky JV. Stress in critical care nurses: actual and perceived. Heart and Lung 2000;25(5):409-417.

9. Sarafino EP. Health Psychology 2002. Biopsychosocial Interactions, 4th edn, Chapter 3. Stress - Its Meaning, Impact and Sources. John Wiley \& Sons, New York, pp. 70-96.

10. Elizabeth MA. A pilot study quantifying Filipino Nurses Perception of Stress. California Journal of Health Promotion 2006;4(4):88-95.

11. Li J, Lambert VA. (2008) Workplace stressors, coping, demographics, and job satisfaction in Chinese Intensive care Nurses. J. of Critical Care Jan-Feb 2008;13(1):12-24. 